Gender, Place \& Culture

A Journal of Feminist Geography

ISSN: 0966-369X (Print) 1360-0524 (Online) Journal homepage: https://www.tandfonline.com/loi/cgpc20

\title{
Rendering responsible, provoking desire: women and home in squatter/slum renewal projects in the Turkish context
}

\section{Tahire Erman \& Burcu Hatiboğlu}

To cite this article: Tahire Erman \& Burcu Hatiboğlu (2017) Rendering responsible, provoking desire: women and home in squatter/slum renewal projects in the Turkish context, Gender, Place \& Culture, 24:9, 1283-1302, DOI: 10.1080/0966369X.2017.1382448

To link to this article: https://doi.org/10.1080/0966369X.2017.1382448

\section{曲 Published online: 03 Oct 2017.}

Submit your article to this journal $\pi$

ЏIII Article views: 385

Q View related articles 5

View Crossmark data \lceil

Citing articles: 5 View citing articles ־ 


\title{
Rendering responsible, provoking desire: women and home in squatter/slum renewal projects in the Turkish context
}

\author{
Tahire Erman ${ }^{\mathrm{a}}$ and Burcu Hatiboğlu ${ }^{\mathrm{b}}$ \\ aDepartment of Political Science and Public Administration, Bilkent University, Ankara, Turkey; \\ bepartment of Social Work, Hacettepe University, Ankara, Turkey
}

\begin{abstract}
This article is situated at the intersection of urban restructuring, cultural conservatism and neoliberalism in the Turkish context to understand the new subject formations of poor women as they are relocated to high-rise apartment blocks in slum/squatter renewal projects by the prospect of homeownership via long-term mortgage loans. It contributes by showing the gendered effects of urban transformation on poor women as neoliberalism and conservatism interact. It draws upon two ethnographic studies that reveal women's experiences embedded both in neoliberalism and patriarchy. In neoliberalism, women's participation in the informal job market was promoted as they were made responsible for contributing to mortgage payments, and they were brought into consumption as they were provoked the desire for good homes via furnishing, and in patriarchy, women's traditional roles in social reproduction were demanded in spite of their new roles and responsibilities. The study ponders women's differentiated negotiations with patriarchy which resisted radical challenges when the family and the home framed women's new responsibilities and desires. The rising conservatism rooted in Islam in Turkey, which prioritizes the family over individual women, created the conditions for it.
\end{abstract}

ARTICLE HISTORY

Received 27 April 2016

Accepted 8 June 2017

\section{KEYWORDS}

Gendered negotiations; neoliberalism; patriarchy; squatter/slum renewal projects; Turkey

\section{Introduction}

This article engages with the broader question of how the lives of poor women in urban areas of the global South transform as cities are restructured by neoliberal projects, and what it means in terms of women's relationship with patriarchy. In the Turkish context, it specifically explores the changes rural migrant women experience as informal neighborhoods are intervened by the state via 'Urban Transformation Projects' (hereafter UTP) to 'redevelop' squatter areas (i.e. housing located on the peripheries of the city with ambiguous legal status) and slum 
areas (i.e. run-down housing in the inner city) by demolishing existing housing. Their residents in turn are relocated in apartment blocks built by the state's neoliberal housing development agency, TOKI (Toplu Konut Idaresi - Mass Housing Administration) after signing up for long-term mortgages for the ownership of their apartments. We ask what new roles and responsibilities women take on when slum/squatter households move to a radically different built environment and are made responsible for homeownership. We contextualize the analysis within neoliberal urban development, coupled by conservative social and gender ideologies led by the Islamist Justice and Development Party (Adalet ve Kalkınma Partisi in Turkish, hereafter AKP). By investigating in what ways women reproduce, challenge or negotiate patriarchy via their new roles and responsibilities, we aim to bring a nuanced understanding of patriarchy embedded in the everyday experiences of women in their new lives in apartments.

We define neoliberalism as'a mode of governance encompassing but not limited to state, and one which produces subjects, forms of citizenship and behavior, and a new organisation of the social' (Brown 2003 cited in Karaman 2013b, 3414); 'in neo-liberalism, the state operates as an agent in the creation of a political culture, where citizens live and act as individual 'entrepreneurs' who are responsible for their own welfare. They perform as consumers, whose political relevance and moral autonomy are measured by their capacity for 'self-care' and by their market value' (Acar and Altunok 2013, 15). We recognize the situated nature of neoliberalism, which takes different forms in different contexts (Brenner and Theodore 2002). In the Turkish context, in its 'paternalistic image as a pious and trustworthy Muslim party of and for the people' (Karaman 2013b, 3415), the government has gained the power to implement neoliberal urban projects rather aggressively. By patriarchy, we refer to a system of gender-based hierarchies of power, which reproduces male domination in variegated forms as it is negotiated differently in different contexts in response to cultural, class-specific and temporal conditions (Kandiyoti 1988). Accordingly, we conceptualize neoliberalism and patriarchy in plural forms. We acknowledge both the possibilities of challenging patriarchy and the constraints that prevent it.

Based on the anticipated relationship between slum/squatter renewal projects and women's new subjectivities, we conducted field research in two sites, both in Ankara, Turkey's capital. One of them is a squatter area located on the city's Northern periphery (Northern Ankara UTP), and the other one in a slum area located at the inner city (Aktaş UTP). For the former case study (April 2010-December 2013), in-depth interviews were conducted with residents in two intervals (60 and 55 participants, respectively), which were complemented by participant observation carried out as the researcher socialized with residents in their everyday lives. And for the latter case study (June 2012-May 2013), in-depth interviews were conducted with 32 women, 17 still living in slum houses and 15 who had moved to TOKI apartments. The interviews were complemented by participant observation during home visits. 
The neoliberal logic of UTPs, which promotes'new modes of subjectivity' (Layton $2014,464)$, is seen in the interventions in slum/squatter areas to release the 'rent gap' (Smith 1987); with the incorporation of residents into the financial system via mortgage loans for homeownership (Karaman 2013a). The responsibilization of the poor for solving their problems in housing is a policy that is not limited to Turkey; in our neoliberal era, supranational institutions, such as the World Bank and the United Nations promote homeownership for slum/ squatter dwellers within a market framework (Jones 2012). Various schemes of homeownership in slum/squatter renewal projects are formulated in the cities of the global South, for example in Mumbai-India and Recife-Brazil (Koster and Nuijten 2012; Roy 2009). The analysis of these projects, however, remains un-gendered. Before we discuss the changes in the lives of women via the UTPs, we review the literature on poor women's relationship with neoliberalism in the global South built upon the double workings of responsibilization and desire creation.

\section{Neoliberalism and poor women in the global South: responsibilization and desire creation}

The neoliberal paradigm is highly gendered; in its assumption of a rational economic self and celebration of the market, it ignores social reproduction, rendering invisible women's unpaid work in the family (Bakker 2003, 2007; Peterson 2005). In the global South, poor women are promoted as hardworking, disciplined and docile workers producing for the world market, which is criticized for integrating women into the market as subordinate actors (Medley and Lorrayne 2004; Wilson 2015). The necessity to balance work and familial responsibilities legitimizes a flexible work regime for women, which erodes their right to secure employment and old-age pension (Hassim and Razavi 2006); it dilutes their status as workers (Erman 2001). Under the prevalence of the market logic, neoliberalism also envisions poor women as entrepreneurs via micro credits, which are presented as a big opportunity (Cheston and Kuhn 2002). However, as an ethnographic study conducted in Turkey has demonstrated, entrepreneurial women's experiences of exhaustion under their new responsibilities while keeping their traditional gender roles belie the idea of poor women's empowerment via microfinancing (Altan-Olcay 2014). Microcredit programs also affect husbands relationally, as they take on the role of pressuring their wives into taking microcredit loans and yet keep them responsible for loan repayments; in other words, they act as agents of microfinance institutions, which creates gender tensions within the family (Cons and Paprock 2010).

In the dismantling of the welfare state, the family is envisioned as the site of communitarian support, and women are responsibilized in multiple ways, such as for the economic survival of their families (Chant 2008), for home-based care work (Altan-Olcay 2014), and for community work (Patel 2016). It causes their exploitation as they become an integral part of the welfare system as providers of un(der)paid home-based care (Dedeoğlu 2013), and as they offer free labor in 
community development, this is then discursively promoted as women's empowerment (Miraftab 2004). In other words, it rests upon the definition of women's community work as a 'natural extension of their role in social reproduction' (Roy 2009, 168).

Being resilient is another feature attributed to women, as they are expected to cope with their triple burden of housework, paid work and community work. James (2013) extends his discussions on post-colonialism to include gender politics of resilience within the aegis of neoliberalism: under neoliberalism, he argues, poor women of the global South are constructed as resilient subjects who can manage the responsibility of bringing home money and providing care and services for family members. When this resilience anticipated from women cannot materialize, they become part of the punitive subjectification of neoliberal governmentality (Hamann 2006). As this focus of neoliberal governmentality on women sharpens, the power of men is eroded in new family arrangements, creating a crisis in masculine identity and posing new challenges to gendered social roles, oftentimes ending up with masculine aggression against women (Connell 2006).

Neoliberal ideology works to capture individual minds by creating desires for 'more' in their lives (Sorrells 2009). This 'desire discourse' incorporates lower classes by the narrative 'you can succeed if you work hard enough'; and women, in their role as homemakers, become a primary target, adding a consumptive desire to their roles of economic survival and social reproduction. Backing up our assertion, Shyamolima (2015) presents the argument that the imaginary of the new Indian women is constructed as actively desiring, i.e. 'the confidant modern consumer woman who is capable of managing both home and work' (365).

The discussion of poor women in neoliberalism extends to include slum/ squatter renewal projects only in a few cases, in which women are discursively nurtured as problem-solvers in multiple ways. Grounded in the ideals of gendered domesticity, not only are they approached by the state for their 'nonconfrontational participation' in the execution of projects, but also as disciplined, willful and self-sacrificing subjects willing to contribute to the social welfare of their families and communities; they are chosen by the state for their contributions to the sustainability of projects (Doshi 2013; Roy 2009). Accordingly slum subjectivities are constructed through 'gendered discourses that elevate women's involvement both as development solution and as a benefit to the poor' (Doshi $2013,857)$. Yet women lack participation in decision-making in projects, particularly if it is legitimized by religious beliefs (Kahuri 2010).

We expect that women's responsibilization for coping with the financial troubles in their families will produce some changes in gender relations, bringing new negotiations with patriarchy. The link between conservatism, which defines women's roles and identities via the social reproduction of family members, and neoliberalism, which responsibilizes poor women for the economic survival of their families, is a complex one, which, as Mies (2001) has demonstrated, can however be reworked to consolidate patriarchy. 


\section{Neoliberal political rationality, conservative cultural politics and urban} transformation in the Turkish context

Turkey is being transformed fast by the coupling of neoliberalism and conservatism under the governing AKP. Neoliberal policies, which were initiated in the 1980s in the aftermath of a military coup, evolved into a more radical form when the AKP, which was defined as a 'socially conservative and economically liberal government' (Buğra 2012, 24), came to power in 2002. Interestingly, in the AKP's early era (2002-2007) some attempts of democratization were made under the tutelage of EU accession process, such as the promotion of civil society organizations; yet they were increasingly Islamized under the rule of the AKP (Göçmen 2014). Policies that had potentially positive outcomes for gender equality were also adopted in this era (Acar and Altunok 2013; Dedeoğlu 2013), which lost its impetus after 2007 as the AKP increased its voting base and embraced a sharper conservative stance, challenging the gender equality discourse of the Republic. The president (formerly the prime minister) in his public speeches actively promotes the family institution, justifying the gendered division of labor in the family by biological differences between the sexes; he also encourages families to increase the number of children, promising payments where there are more than three children. Accordingly, cultural conservatism, which'naturalize(s) gender roles (and) gender inequality' (Brown 2004), is injected into private lives by the state. Conservative 'politics of intimate' constitutes the moral base of neoliberal political rationality in the Turkish context (Acar and Altunok 2013).

In Turkey, while new patriarchal flexibilities emerged under the forces of modernization promoted by urbanization since the 1950s, the promise of women's liberation in an urbanized society remained largely unfulfilled due to the nature of Turkish urbanization characterized by mass migration from the countryside. In the rural migrant families in the city, the traditional family model, which rests on the assumption that husbands provide for material needs and wives provide care services, prevails; being a housewife signifies the husband's economic success and consolidates his role as the guardian of the family honor (namus) by keeping his wife in the private realm (Erman 2001).

As the family and women's gendered roles as wives and mothers are promoted by the ruling party in a context that has largely remained on the periphery of modernity, the idea of women as individuals who are entitled to make their own decisions about their lives is losing ground. Gains of the feminist movement, which found the chance to blossom in the aftermath of the 1980 military coup when class-based mobilizations were violently suppressed by the army, are eroding fast. The patriarchal model is widening its appeal under the AKP rule. Yet when the patriarchal provider's earnings wear away due to neoliberal policies, women in poor families increasingly take on economic roles. In the attempt to protect patriarchy from new challenges, women's economic contributions are defined as 'pocket money' (Erman 2001). To manage the threats brought by women's working 
outside the home to the family honor defined via women in Turkish patriarchy, various strategies are undertaken: poor women are employed in the informal sector or engaged in home-based work (Soytemel 2013); they offer their unpaid labor in family businesses as they negotiate with kinship relations of reciprocity and obligation in which they benefit from long-term security in exchange of unpaid labor (White 1994); they prefer workshops located inside or close to their neighborhoods to where they can walk in groups (Erman 2001).

Surviving as a family goes hand in hand with moving up as a family. Under the tutelage of neoliberalism, as the values of society evolve towards celebrating wealth and consumerism, and the availability of bank credits creates the chance of increased engagement with the market, including homeownership via longterm mortgage loans, women in poor families aspire for more. This is observed in a group of women employed by the better-off classes as domestic workers, whose desire for apartment ownership, the bigger the apartments the better, kept them working hard under disadvantaged conditions including long-distance commute to the homes of their employers who had moved out to the suburbs in distant locations (Kara 2016).

In the 'return of the family' (Yazıcı 2012), women in poor families are responsibilized via the welfare system and programs of conditional cash transfer, such as caregiving to the elderly, the sick and the disabled in their families (830 TL, paid if the family income is less than the minimum wage) and making sure that children attend school (40 TL for each child). Among the providers of social assistance in Turkey, the General Directorate of Social Assistance and Solidarity (SYDGM) is the main actor, together with municipalities and NGOs. SYDGM is far from functioning as part of a welfare system; under the populism and neoliberal mentality of the ruling party, it provides conditional in-kind and cash social assistance rather than 'basic income' to poor families. Municipalities distribute coal and food irregularly since this practice is based on populist motives rather than structured as part of the state's welfare system (Buğra 2012); and NGOs in welfare provision are increasingly 'religiously-motivated' (Göçmen 2014).

The AKP government is known for its slum/squatter renewal projects for rent generation, which is transforming the relationship between the state and the poor. In the earlier era of popular urbanization, the clientalistic relationship between the state and rural migrants worked to the advantage of the poor as political parties sought patronage by promising land titles and basic urban amenities to informal neighborhoods. This has changed today in the regime of neoliberal urbanism in which the state opens peripheral land for'redevelopment' by the private sector for profit. As the urban poor lose their informal housing as an affordable way of life, their dependency on the government deepens, subjecting them to the conservative values of the AKP:'The common perception among aid recipients is that one needs to have close ties to the AKP and/or follow Islamic codes of daily conduct' (Karaman 2013b, 3423). In this new urban regime, slum/squatter renewal projects are presented as development projects with the promise of improved lives, both 
in terms of physical conveniences and safety issues. Accordingly, the apartment life has become the trope of marketing a better life for slum/squatter residents. Paradoxically, the apartment, which was promoted in the early Republic to modernize/westernize people by living as nuclear families (Gürel 2009), is promoted in TOKI projects due to profit concerns; it contradicts with AKP's ideological association with traditional community-oriented lives. This discourse of better life in apartments prevails in the two case studies that provide the context to discuss the gendered effects of slum/squatter renewal projects, namely the Northern Ankara UTP for the squatter site on the city's periphery, and the Aktaş UTP for the slum site at the inner city.

\section{Case studies: the Northern Ankara UTP and Aktaş UTP}

The Northern Ankara and Aktaş UTPs differed from each other in terms of the degree of legality of property (land and house), the level of the physical quality of houses, and the characteristics of the local population before the demolitions. The Northern Ankara UTP covered a large area that included those neighborhoods in a remote location that had remained out of the formalization process of squatter housing via land titles and thus these families owned their houses but not the land on which they were built. In contrast, the Aktaş neighborhood was one of the first squatter settlements built in the 1950s, which ended up at the inner city in the expansion of the city towards its peripheries, and most of the owners secured land titles over the years. Built years ago during the first wave of rural-to-urban migration in the 1950s, the houses in Aktaş were deteriorating, which contrasted with the gecekondus (Turkish term for squatter housing) built on the city's periphery, mostly single-family houses with gardens, some of which had turned into sturdy houses over the years, as families, in their belief that their houses would not be destroyed by authorities, had invested in them. In Aktaş the very poor Kurdish, Turkish and Roman people at the bottom of society lived (none of the groups was politicized), whereas the Northern gecekondu area housed mostly those ruralto-urban migrants who moved to the city from the villages of the northern provinces of Central Anatolia, the majority being Sunni Muslim Turks.

The UTPs implemented in the two sites shared similarities due to the neoliberal position of the projects, with some minor differences in the compensation schemes. In the first project, squatter owners without title deeds would get an apartment $\left(80 \mathrm{~m}^{2}\right)$ in the housing estate to be built by TOKI in Karacaören (hereafter K-TOKI) and sold to people by subsidized mortgage loans. The monthly mortgage installments would be paid to a public bank, causing residents to complain because of the fact that banks impose a rigid and regular payment scheme and do not respond to their clients' employment conditions. Despite the tendency of poor women's increased engagement in paid work since the introduction of structural adjustment programs in the early 1980s, the women in this project were mostly housewives when they lived in the gecekondu, which may be due to the distant 
location of their squatter neighborhood and their modest and cheap way of life, keeping them, to some extent, out of the capitalist urban life. In their case, paying apartment installments initially fell into the realm of the husbands' responsibility, which was not possible in most cases due to their low and in some cases irregular wages (e.g. seasonal construction workers). In their gecekondu lives and especially during the waiting time for relocation, many families received municipality's aid of coal and food packages, and some continued receiving the latter after they moved to K-TOKI (14/60), always with the possibility of losing it. In the second project, slum owners would get an apartment $\left(120 \mathrm{~m}^{2}\right)$ in exchange of $150 \mathrm{~m}^{2}$ of land. However, despite the fact that most slum owners had titled land and qualified as 'rightful owners,' they were disadvantaged because of their very small plots due to the land's being divided over the years through inheritance, and they had to pay the difference to be entitled for an apartment. In their dependency on the support provided by the General Directorate of Social Assistance and Solidarity (Sosyal Yardımlaşma ve Dayanışma Genel Müdürlüğü, hereafter SYDGM), it contradicted significantly with their economic positions. Ironically, their installments were higher than in the first project because of the fact that inner-city apartments, which were designed as large homes to be sold to the middle-classes, had higher prices; while the starting monthly payment was about $200 \mathrm{TL}$ in the first project, it was between $400 \mathrm{TL}$ and $700 \mathrm{TL}$ in the second project.

In their gendered attributes as reliable and responsible subjects for the welfare of their families, women were targeted by social assistance and charity institutions, and, in their thinking of search for social aid as bringing disgrace to manhood, husbands kept themselves away from any engagement with it, making social assistance women's domain. Accordingly, since it was women who received social assistance and husbands were either unemployed or very poorly connected to the job market mostly informally, apartment payments became women's responsibility. Although the expectation that the families survived by social assistance would become homeowners by their own means was unrealistic, it fitted well with the workfare mentality of neoliberalism that pressures the poor to work harder by incorporating them into the system via debts. The requirement that families should keep their eligible status for social assistance (the family income should be below a particular amount) deepened the paradox when new income-generating activities were needed to be able to pay the apartment installments. This caused some families to fall out of the system of social assistance.

Women were vocal in their complaints about the state's diminishing support following the UTP: 'Before the project, we had the father state, but now we have TOKI.' Below we discuss the gendered effects of slum/squatter renewal projects based on the two recurring themes in the fieldwork, namely, the responsibilization of women in their families and their desire for a good home. 


\section{Familization of responsibility and women's desire for a good home}

\section{'I am doing it for my family': women's new familial responsibilities}

In this section, we examine women's access to the public sphere in their new roles of income-generation as workers and/or recipients of social assistance and discuss the negotiations with patriarchy it might entail. We recognize women's practices in the private sphere in their role of social reproduction in a physical environment that failed to qualify for an economically and culturally sustainable way of life.

In their previous lives in the gecekondu, the women in the first project had embraced their position in the family as housewives: in their migration to the city, one main motive was to become housewives in their nuclear families, nicely summarized in this quotation: 'I moved to the city to be the woman of my house.' In many households, there was a reserved attitude towards women's working outside the home, with reasons related to the family honor. Their everyday life in the gecekondu evolved around doing house chores and caring for children. Different from middle-class housewives who would carry out their tasks alone inside their apartments, these women would do them in the semi-public/semi-private spaces around their houses, oftentimes collectively with their neighbors. They would socialize while doing chores outdoors; they would join neighborly gatherings in front of their houses, knitting or crocheting while chatting, they would do winter preparations, such as 'winter bread,' tarhana (dried soup) and erişte (stripped pasta), taking turns with neighbors. This intimacy and support among neighbors, as many respondents said, created satisfaction in their lives, who would otherwise suffer from their exclusion from urban opportunities. Yet it did not challenge the authority of husbands: in outdoor gatherings, many women would have their eyes on their arriving husbands, alarmed to go inside to serve the husbands. The women in the second project, on the other hand, had lost their chance of outdoor socialization before the UTP was launched due to the growth of slums in the area. Vacant houses attracted criminal groups and drug addicts, which created an unsafe environment, forcing women to stay behind doors. Accordingly, in their desire for clean, comfortable and safe homes promoted in the municipality's discourse of a civilized life, they supported the mayor's UTP.

Women's contributions in their gecekondu lives by producing food stuff could not be reproduced in the apartment context, taking off the economic advantages that they had in the gecekondu. This was coupled by the increased expenses in the formalization of their lives in apartments, such as paying maintenance fees for the services they used to do in their lives in the gecekondu (e.g. cleaning in front of their houses and taking the garbage out) and buying vegetables and fruits in the market, some of which they used to produce in their gecekondu gardens. More importantly, in many male provider families, despite their effort to find a second job or work at night shifts mostly in the informal sector, husbands' incomes were short of paying mortgage installments, all of which necessitated women's paid 
employment, which was accompanied by the placement of grown-up daughters in paid work in some cases.

Women's employment outside the home came as a contested issue, both men and women embracing or challenging it to varying degrees. 'I am doing it for my family' was the justification of those women interested in paid work, which would in fact benefit the husbands since in most cases husbands would be the ones to own the titles of apartments upon the completion of mortgage payments. This phrase came to be part of the emerging discursive regime that defined women's new responsibilities in the family. In the case of husbands' disagreement with their wives' working outside the home, which became more strict and legitimate when the husband was gainfully and securely employed (there were very few), tension arose in some families. Serpil (29), who desired to belong to the modern middle classes (different from most of the women in K-TOKI, she would not cover her hair), was very frustrated and angry at her husband (a salesman in a shoe store) when he did not permit her to go back to her old job in a pharmacy where she used to work before she got married. This created disputes in the family, occasionally ending up with the husband getting physically violent. Some women, however, did contest the emerging norm of women's working outside the home, saying that they could not work because of their old age and/or health problems, or their young/ sick children. The conservative discourse, in which families with working mothers were seen as a problem because of 'children's growing up unattended,' supported the latter's claims. The new definition of women's responsibilities, which carried the possibility of women's empowerment, was devoid of challenges to the status of women as housewives in patriarchal arrangements: the women in our research were mostly employed in the informal sector, and only a few in the formal sector in jobs that were the extension of housewifely duties such as cleaning, cooking and caregiving.

As discussed above, in the commitment of families to pay mortgage installments, women started having the opportunity of moving into the public sphere for employment. Feminist scholars consider women's access to the public sphere as an opportunity structure, offering them possibilities by taking them beyond their private lives framed by the imperatives of patriarchy. However, as we observed in the two field studies, the presence of women in the public sphere came with new patriarchal control mechanisms. Targeting to incorporate poor women as cheap and unorganized labor force, neoliberalism had to respond to the concerns of patriarchy. For example, in the road landscaping projects of the municipality's subcontracting firm for which many women from K-TOKI worked, 'sergeant women' were commissioned by the firm as mediators; they collected women from the housing estate, accompanied them as women were carried in trucks to specific localities where they would plant flowers and lay down grass sheets along the road borders, all along taking responsibility for them. Accordingly, they acted as a buffer mechanism between the male public realm and individual female laborers. Responding to the concerns of men about the family honor when 'their women' 
were out to work, this practice secured the conservative view of women under surveillance.

Moving to the apartment estate simultaneously drew women out into public spaces and kept them inside their apartments. On the one hand, from living in an environment of strangers, especially young women's use of outdoors around their houses to socialize with neighbors was prohibited by the husbands in their concern with the family honor. On the other hand, taking on the new role of contributing to the family budget and in some cases shouldering the responsibility of coping with the new financial burden in apartments all by themselves, women entered public spaces for goal-oriented activities, such as shopping and searching for social assistance. Yet their presence in public spaces was regulated by the socially gendered codes of behavior built upon family honor. When the apartment life rendered families increasingly dependent on the market, bringing women new responsibilities of finding the cheapest products sold in the markets, the women in K-TOKI would usually go out to the estate's shopping center in the company of their neighbors, relatives, and/or children. Similarly, public spaces into which women entered while searching social assistance were dominated by conservative values shaped by Islamic groups that would offer economic, social and psychological support for women. Akkız, a woman of 32, who had five children and who faced the risk of losing her apartment (bailiffs came when her husband could not pay the mortgage installments for several months, taking away the television set), started having rashes which kept her awake at nights; she found the cure by attending religious meetings of an Islamic organization which gave her emotional comfort and helped her widen her social circle, ending her isolation in her new apartment. Especially all-women's religious talks (sohbetler) and Quran courses were popular among the majority of the poor women in the research. Being Sunni Muslims, they differed from those few women belonging to the Alevi sect, which, in its boundary-making, prides itself upon gender equality and supports the secular establishment (Massicard 2013). Moreover, as women were responsibilized for social assistance and NGOs were Islamized under the AKP rule, this created the conditions for women's engagement with religious conservatism which worked to justify their submissiveness to male domination. In sum, the public sphere, to which the women in our research had new means of access as a result of their responsibilization for the economic survival of their families, was shaped both by conservative values and neoliberal practices, embedding them more deeply into the patriarchal structure while exploiting their labor.

Bringing in their agency, women would engage in new negotiations with patriarchy emerging from their increased responsibilities, which were based upon their interpretations of their husbands as 'deficient men' or not. Under the pressure to keep the option of homeownership, some women became demanding of their husbands, whereas others did not. Yeter, a middle-aged mother of six, exemplified the latter group of women. She had two grown-up sons and a husband to feed so that they could bring home money by working in constructions, made 30 loaves 
of bread weekly in her apartment on a gas burner placed on the floor of her poorly furnished living room, despite the neighbors' complaints about the smell. Her view of the men in her family as working hard when they had a job justified her rather extreme efforts of food production in the apartment setting. Refreshingly other women, such as Ayşe (24), a former slum dweller and a mother of two young children with an unemployed husband whom she believed to be too lazy to get a job, demanded that her husband should try harder to bring home some money, which she believed necessary to overcome the financial obstacle to her goal of homeownership.

This confrontational position of women brought by the new conditions was counteracted by the traditional view of docile women who would do their best of what the husband could provide. As a woman respondent put it: 'Koca getirir, karı yetirir' (The husband provides, the wife suffices, i.e. makes it sufficient for the family's needs). It rendered invisible the efforts of the women on social assistance for the survival of their families, as complained by Fatma (29), another slum dweller whose husband was irregularly employed in the open market: 'All the burden of sustaining a living for my family rests on my shoulders. I do everything for my family. And yet I have to pretend that I do not.'It furthermore sharpened women's concerns to economize. In the slum renewal project, Hatice (35), whose employment outside the home was strictly prohibited by her husband, would wash herself standing in a container, using the water accumulated in it to clean the toilet or wash the balcony. Many women in our research did not turn on the radiators during Winter days, sitting in the cold until the husbands arrived, falsifying the promise for a comfortable life in apartments heated by natural gas. Interpreting it as something they should do for their families, they did not question these gender-based disadvantages. Accordingly, engaging in practices of economizing was also gendered.

The resilience of women that derived from their desire for apartment ownership led to managing their new roles without reformulating their traditional gender responsibilities; it was acted upon to protect the patriarchal family against the destabilizing potential of women's waged employment. However, women's resilience was belied in reality: under the stress of double burden, many women had health problems, including psychological ones, shattering their image of resilient women under new challenges. Despite some challenges by the younger women, the continuing hegemony of the ideal of docile women, moreover, helped to maintain the conservative patriarchal bargain.

\section{'I desire my apartment well-furnished': patriarchal negotiations in homemaking via consumption}

The home is the place to perform neoliberal subjectivities in the better-off classes, both by becoming homeowners, which is promoted more in the post-1980 era, and by decorating houses to reflect their privileged social status (Bowlby, Gregory, and 
McKie 1997). The traditional role of women as homemakers gains new meanings when the home is defined as the symbol of the family's success measured in terms of consumption (Sorrells 2009). Although this idea holds true more for middle and upper-class families, lower-class families also come under the influence of this ideology. Inspired by the idea of home-making via consumption, poor women also aspire to consume to catch up with the idealized neoliberal feminine subjectivity.

In our research, many women tended to pursuit the goal of home consumption. This emerged not merely from need but also from desire. Desire, which is defined by Gill (2008) as part of the 'affective dimensions of ideology', fueled consumption in their approach to their apartments. The social expectation among rural-to-urban migrants that they should be active in consumption in order to feel belonging to the city, which had developed in response to the rejection of their socio-cultural integration by the urban elite, formed the cultural basis of this neoliberal desire provoking. Moreover, in its established view as the place of urban middle-classes in Turkish society, rural-to-urban migrants perceive the apartment as a means of social mobility (Erman 1996). Thus, conscious of the apartment as status symbol, many women in K-TOKI were committed to furnishing their new places. Under their limited economic resources, families gave priority to their guest rooms, furnishing them with new sofa and dining sets, carpets and curtains, attention paid to matching colors, and women's hand products decorating walls, television sets and curtains. In the words of a woman who had the propensity for social mobility:

When you live in an apartment, you are motivated to do more for your home. 'Let's do this, let's buy that.' Inevitably, you move towards luxury. In the gecekondu, you settle with what you have. In the apartment, you cannot have the same carpet you use in the gecekondu. It does not fit with the view of what an apartment should be like. We completely renewed our furniture, carpets, curtains. You want your apartment look good. You desire for the best. [Zehra, born in 1980, moved to the city when she got married, housewife, husband an ironsmith]

As their apartments became the center of their new subjectivities, these women were concerned about keeping them clean and tidy, which increased spending money on the home:

The apartment shows when it is not well-kept. In the gecekondu, you wash the concrete floor with a bucket of water, and your house is clean. But in the apartment, you have to pay attention to the parquet floors, to the kitchen tiles; you should clean them with different detergents, and make sure that your place is clean and tidy. It is very costly. [Nihal, born in 1970, moved to the city when she was a child, housewife, husband run a small restaurant]

In the case of the few women who could afford being housewives in their relatively better-off families, both the interests of neoliberalism which is built on the premises of consumerism, and cultural conservatism which defines women in relation to the home, were served. In women's relationship with consumerism, patriarchal order was maintained in most cases and challenged in other cases. The wives working for new furniture were expected to act as resilient subjects in 
order to prevent domestic conflicts. Husbands would not be happy with the new arrangements when their wives worked outside for long hours if it was to buy new furniture and not to pay mortgage installments. This is narrated by Nigar, a middle-aged woman who took the initiative to work in a temporary job to buy new furniture:

For seven months, I was at work from seven in the morning until midnight. I learned coming home late at night like men. I was making pastries for a restaurant. My husband got cross with me, complaining about eating the same simple food every day. He told me to leave the job, I said No. I did this to buy this sofa set.

This created a potential crisis in the family when the husbands' expectations from their wives failed. It was prevented in some families if the wife responded by trying not to neglect her housewifely duties while working outside the home, while in few others new gender negotiations emerged yet only temporarily. The desire created via apartment living for well-furnished homes brought new challenges to traditional patriarchal bargains when mostly young women demanded their husbands to provide for new home furnishing; this was so especially if their wish to work outside the home was rejected by the husbands, producing new challenges to patriarchy. Songül, a young woman with middle-class aspirations, a mother of a young son, whose husband worked in a shoe store, said: 'Of course we argue. We even get physical, he hits me. When I ask him why he did not buy this or that piece of furniture, we start fighting.' As the quotation demonstrates, women may face the risk of domestic violence when they make demands from their husbands, breaking the traditional patriarchal contract in a context devoid of political support for gender equality. This emerging demanding attitude of young women was counteracted by older women, i.e. those with grown-up children, who criticized them for being captured by desire; in their established bargain with patriarchy, they defended their traditional roles as 'docile wives,' creating a contested social environment among women. Safure (41), whose husband was a construction worker, criticized them: 'There are those who fight with their husbands when they cannot have new furniture. They even get into depression. There is not such a rule that everyone has to renew their furniture. Some go into so much debt that their lives are ruined.' Attributing the blame of domestic disputes to 'demanding wives,' Safure served to protect the patriarchal family against new challenges. Women's position in home-based consumption was differentiated along the axis of the neoliberal feminine subjectivity on the one hand, making demands from their husbands so that they could be active consumers, with traditional feminine subjectivity registering content with what their husbands could provide.

The fact that in most families buying new furniture meant going into further debt and creating the risk of defaulting on mortgage payments produced dilemmas in K-TOKI ('homemaking via furnishing' vs. 'homeownership via mortgage payments'). It divided women as those who approved going into debt for new furniture ('This is all debt, we bought everything anew. You eat cheap food and buy it. No problem'), and those who disagreed ('If her family has a good income, 
of course she will spend money on her new home. But if she buys furniture while she has the apartment debt to pay, this is $\left.\sin ^{\prime}\right)$. Hence these practices initiated confrontations and created new vulnerabilities.

In Aktaş-TOKI, the case of former slum women destabilized the framework of feminine subjectivity as consumers in neoliberalism and as docile women in traditional patriarchy in which the husband assumes the breadwinner role. A major paradox was about women's desire for 'better' homes exacerbated by the mayor's promise of a civilized life in apartments and their position as surviving on social assistance. On the one hand, in the consumerist society, they had become well aware of how their new apartments should be like, and on the other hand, they could not be consumers in the market. They relied on other people's generosity for home furnishing. Hasibe, a young woman whose husband was unemployed, showed with resentment the only piece of furniture she could buy by using the money given to her during the Ramadan alms-giving - a coffee table, saying that she needed much more. For the majority in this group, much like continuing to live in their apartments in the future, buying new furniture was an impossible dream. Not knowing how long they could stay in their apartments, they were in a state of tenancy, as expressed by Meryem (47) whose husband worked irregularly in the local open market and who received conditional cash transfer from SYDGM for the education of her three children aged 11, 12 and 13:

We are living among this dirty furniture like tenants. We give our priority to apartment payments but still we cannot manage to pay them. I am so worried that they will kick us out anytime. We are living on the border.

Her family was expected to pay 250 Turkish liras each month regularly for 15 years as mortgage loan so that they would be entitled to an apartment in exchange of their $70 \mathrm{~m}^{2}$ of land. Under such conditions of vulnerability and temporariness, spending money on new furniture was just not possible.

Another paradox was about women's desire for well-furnished homes and their status as the recipients of social assistance from SYDGM. When the authorities noticed refrigerators or sofa beds, always second-hand, during their visits to check on the living conditions of their recipients, they would take them off their list. Emine (34), a former slum dweller, who was under the pressure of making mortgage payments while keeping her four daughters in school, complained about the approach of the SYDGM authorities:

We truly need help more than ever after we moved to the apartment. But they wouldn't understand. They come and say, "Look, you have a vacuum cleaner." Come on, look at it, it doesn't work. Everything here, I collected them here and there. They are old and broken. But they wouldn't understand, they wouldn't listen.

In brief, the desire created via apartment living for well-furnished homes brought new challenges to traditional patriarchal bargains as mostly young women demanded their husbands to provide for new home furnishing. It hence challenged the traditional patriarchal bargain, with the new bargaining positions of 
women in K-TOKI not being reproduced in the case of the families surviving by social assistance in Aktaş-TOKI.

\section{Conclusion}

This article has demonstrated the significance of looking at neoliberal urban development through the gender lens. It has contributed to the literature by offering a fresh perspective on women's new subjectivities upon their move to a radically different built environment of high-rise apartment blocks in squatter/slum renewal projects. Embedding neoliberal urban development in an increasingly conservative society in the Turkish context, it has pointed out to the potentiality of ruptures in traditional gender roles and new negotiations with patriarchy, which could be brought by women's new roles and responsibilities, yet this potentiality was impeded to a significant extent. Responsibilized for homeownership and provoked by the desire for well-furnished apartments, and the family and the home framing their new subjectivities, the women in the two case studies were willing to increase their workload, which tested their resilience. In both cases, they were increasingly immersed into the conservative/Islamist public sphere which strengthened their commitments to their families as submissive subjects.

In K-TOKI, a potential crisis in conservative masculinities triggered by the inability of husbands to be sole breadwinners in the apartment context could be prevented to a large extent by the commitment of wives to their apartments cultivated by the ideology of apartment ownership via UTPs. Their goal of keeping their apartments and making them nice places to live could be attained only via the family, which is defined as the only proper way of being for women in the conservative value system of the AKP. Despite their contributions by working outside the home, they did not challenge the established traditional gender order, preserving their docile feminine roles. Offering their cheap and flexible labor in the informal market, they were not conferred the status of working women. The exceptions to docile women were some young women who wanted to work to improve their lives and/ or wanted to possess new home furniture in their apartments, but the husbands acted to prevent them from achieving their goals. In the case of Aktaş-TOKI, the ideal of docile women was disturbed when women attributed the impossibility of becoming homeowners to the laziness of their husbands, demanding them to contribute to monthly mortgage payments. Challenging the husbands' authority, it caused crises in the family and often subjected women to violence. The AKP's conservative discourse that places the patriarchal provider family model at the core and its neoliberal policies that aim to incorporate men in poor families into the market as cheap labor force strengthened women's demands from their husbands as the'head of the family.'Thus, the masculinity crisis often causing violence against women is more visible in the slum renewal context in which husbands depend on their wives' access to social assistance. 
To sum up, under the double workings of neoliberalism, which made homeownership available and desirable to economically disadvantaged families and the consolidation of cultural conservatism in the AKP era, which defined women as devoted mothers and wives working for the interest of their families and men as the head of the family, women's new subjectivities were framed along the axis of their resilience. On the one hand, it reproduced the ideal of docile women in patriarchal family arrangements; and on the other hand, it produced new challenges to the established gender order in the family that were prone to crises in slum/squatter masculinities when women started asking their husbands to take the responsibility of responding to the new needs and/or their desires that arose in the apartment context.

\section{Disclosure statement}

No potential conflict of interest was reported by the authors.

\section{Funding}

The work of the corresponding author was supported by the Scientific and Technological Research Council of Turkey (TUBITAK) [grant number 109K360]; and the work of the co-author was supported by the Scientific Research Projects Coordination Unit of Hacettepe University [grant number 012D06701002].

\section{Notes on contributors}

Tahire Erman is associate professor at Bilkent University, Department of Political Science and Public Administration. Her main research interests include urban informality, poverty, gender issues, housing of the poor, urban restructuring, and migration/mobilities. She published in such journals as Gender \& Society, Women's Studies International Forum, Environment and Planning A, International Journal of Urban and Regional Research, Urban Studies, International Journal of Middle East Studies, Middle Eastern Studies, Environment and Behavior, Habitat International, International Journal of Turkish Studies, Urban Anthropology, and Ethnologie Française. She was awarded the 'Donald Robertson Memorial Prize' for the best article published in Urban Studies in 2001. She received Fulbright Senior Scholar Grant for the academic year 2005-2006, appointed jointly by the Social Anthropology Department and Center for Middle Eastern Studies, Harvard University.

Burcu Hatiboğlu is a research assistant in the Social Work Department at the University of Hacettepe. Her research interests include poverty reduction, social services, urbanism, gender issues and feminist social work. Her doctoral thesis investigated how the daily lives of women changed within the framework of neoliberal urbanization by focusing on the case of the Aktas district of Ankara. She is also a board member of the Social Policies Research and Application Center and is a committee member for Women Platform at the University of Hacettepe. 


\section{References}

Acar, Feride, and Gülbanu Altunok. 2013. "The 'Politics of Intimate' at the Intersection of Neoliberalism and Neo-conservatism in Contemporary Turkey." Women's Studies International Forum 41: 14-23.

Altan-Olcay, Özlem. 2014. “Entrepreneurial Subjectivities and Gendered Complexities: Neoliberal Citizenship in Turkey." Feminist Economics 20 (4): 235-259.

Bakker, Isabella. 2003. “Neo-liberal Governance and the Reprivatization of Social Reproduction: Social Provisioning and Shifting Gender Orders." In Power, Production and Social Reproduction: Human in/Security in the Global Political Economy, edited by S. Gill and I. Bakker, 66-82. New York: Palgrave Macmillan.

Bakker, Isabella. 2007. "Social Reproduction and the Constitution of a Gendered Political Economy." New Political Economy 12 (4): 541-556.

Bowlby, Sophie, Susan Gregory, and Linda McKie. 1997. "'Doing Home': Patriarchy, Caring, and Space." Women's Studies International Forum 20 (3): 343-350.

Brenner, Neil, and Nik Theodore. 2002. "Cities and the Geographies of 'Actually Existing Neoliberalism.' Antipode 34 (3): 349-379.

Brown, Michael. 2004. “Between Neoliberalism and Cultural Conservatism: Spatial Divisions and Multiplications of Hospice Labor in the United States." Gender, Place and Culture 11 (1): 67-82.

Buğra, Ayşe. 2012. "The Changing Welfare Regime of Turkey: Neoliberalism, Cultural Conservatism and Social Solidarity Redefined." In Gender and Society in Turkey: The Impact of Neoliberal Policies, Political Islam and EU Accession, edited by S. Dedeoğlu and A. Y. Elveren, 15-31. London: I.B. Tauris.

Chant, Sylvia. 2008. "The 'Feminisation of Poverty' and the 'Feminisation' of Anti-Poverty Programmes: Room for Revision?" The Journal of Development Studies 44 (2): 165-197.

Cheston, Susy, and Lisa Kuhn. 2002. "Empowering Women through Microfinance." In Pathways out of Poverty: Innovations in Microfinance for the Poorest Families, edited by S. Daley-Harris, 167-228. Bloomfiled, CT: Kumarian Press.

Connell, Raewyn W. 2006. Masculinities. Cambridge: Polity Press.

Cons, Jason, and Konrad Paprock. 2010. "Contested Credit Landscapes: Microcredit, Self-help and Self-determination in Rural Bangladesh." Third World Quarterly 31 (4): 637-654.

Dedeoğlu, Saniye. 2013. "Veiled Europenisation of Welfare State in Turkey: Gender and Social Policy in the 2000s." Women's Studies International Forum 41 (1): 7-13.

Doshi, Sapana. 2013. "The Politics of the Evicted: Redevelopment, Subjectivity, and Difference in Mumbai's Slum Frontier." Antipode 45 (4): 844-865.

Erman, Tahire. 1996. "Women and the Housing Environment: The Experiences of Turkish Migrant Women in Squatter (Gecekondu) and Apartment Housing." Environment and Behavior 28 (6): 764-798.

Erman, Tahire. 2001. "Rural Migrants and Patriarchy in Turkish Cities." International Journal of Urban and Regional Research 25 (1): 118-133.

Gill, Rosalind. 2008. "Culture and Subjectivity in Neoliberal and Postfeminist Times." Subjectivity 25: 432-445.

Göçmen, İpek. 2014. “Religion, Politics and Social Assistance in Turkey: The Rise of Religiously Motivated Associations." Journal of European Social Policy 24 (1): 92-103.

Gürel, Meltem Ö. 2009. “Defining and Living Out the Interior:The "Modern" Apartment and the "Urban" Housewife in Turkey During the 1950s and 1960s." Gender, Place and Culture 16 (6): 703-722.

Hamann, Trent H. 2006. “Neoliberalism, Governmentality and Ethics." Foucault Studies 6: 37-59. 
Hassim, Shireer, and Shahra Razavi. 2006. "Gender and Social Policy in a Global Context: Uncovering the Gendered Structure of 'the Social.' In Gender and Social Policy in a Global Context: Uncovering the Gendered Structure of 'the Social', edited by S. Razavi and S. Hassim, 1-43. New York: Palgrave Macmillan.

James, Robin. 2013. 'Look, I Overcame!': Feminine Subjectivity, Resilience and Multi-Racial White Supremacist Patriarchy." Accessed January 19, 2016. http://www.its-herfactory.com/2013/03/ look-i-overcame

Jones, Branwen Gruffydd. 2012. "'Bankable Slums': The Global Politics of Slum Upgrading." Third World Quarterly 33 (5): 769-789.

Kahuri, Serah Kabui. 2010. "Engendered Land Administration System: Mysore Slums Upgrading." Master's thesis, University of Twente, Faculty of Geo-Information and Earth Observations (ITC), Enschede, the Netherlands.

Kandiyoti, Deniz. 1988. “Bargaining with Patriarchy." Gender \& Society 2 (3): 274-290.

Kara, Hilal. 2016. “Understanding Female Domestic Workers' Daily Mobilities: A Case Study in Ankara." Master's thesis, Middle East Technical University, Ankara.

Karaman, Ozan. 2013a. "Urban Renewal in Istanbul: Reconfigured Spaces, Robotic Lives." International Journal of Urban and Regional Research 37 (2): 715-733.

Karaman, Ozan. 2013b. "Urban Neoliberalism with Islamist Characteristics." Urban Studies 50 (16): 3112-3127.

Koster, Martijn, and Monique Nuijten. 2012. “From Preamble to Post-project Frustrations: The Shaping of a Slum Upgrading Project in Recife, Brazil." Antipode 44 (1): 175-196.

Layton, Lynne. 2014. "Grandiosity, Neoliberalism and Neoconservatism." Psychoanalytic Inquiry: A Topical Journal for Mental Health Professionals 34: 463-474.

Massicard, Elise. 2013. The Alevis in Turkey and Europe: Identity and Managing Territorial Diversity. London: Routledge.

Medley, Joseph, and Carroll Lorrayne. 2004. “The Hungry Ghost: IMF Policy, Global Capitalist Transformation, and Laboring Bodies in Southeast Asia." In Postcolonialism Meets Economics, edited by E. Zein-Elabdin and S. Charusheela, 145-164. London: Routledge.

Mies, Maria. 2001. Patriarchy and Accumulation on a World Scale: Women in the International Divison of Labor. London: Zed.

Miraftab, Faranak. 2004. "Making Neoliberal Governance: The Disempowering Work of Empowerment." International Planning Studies 9 (4): 239-259.

Patel, Sheela. 2016. "How the Women of Mahila Milan in India Learned to Plan, Design, Finance and Build Housing." Environment \& Urbanization 28 (1): 223-240.

Peterson, Spike V. 2005. "How (the Meaning of) Gender Matters in Political Economy?" New Political Economy 10 (4): 499-521.

Roy, Ananya. 2009. "Civic Governmentality: The Politics of Inclusion in Beirut and Mumbai." Antipode 41 (1): 159-179.

Shyamolima, Ghosh Choudhury. 2015. "New Discourses on Womanhood: Exploration of Neoliberal Subjectivities in Contemporary India through a Case Study." Psychological Studies 60 (3): 265-274.

Smith, Neil. 1987. "Gentrification and the Rent Gap." Annals of the Association of American Geographers 77 (3): 462-465.

Sorrells, Kathryn. 2009. “Bringing It Back Home: Producing Neoliberal Subjectivities." Liminalities: A Journal of Performance Studies 5 (5): 1-6.

Soytemel, Ebru. 2013. “The Power of the Powerless: Neighborhood Based Self-help Networks of the Poor in Istanbul." Women's Studies International Forum 41: 76-87.

White, Jenny. 1994. Money Makes Us Relatives: Women's Labor in Urban Turkey. Austin, TX: University of Texas Press. 
Wilson, Kalpana. 2015. "Towards a Radical Re-appropriation: Gender, Development and Neoliberal Feminism." Development and Change 46 (4): 803-832.

Yazıcı, Berna. 2012. "The Return to the Family: Welfare, State, and Politics of the Family in Turkey." Anthropological Quarterly 85 (1): 103-140. 